\title{
Epilogue \\ The Scandal of the Refugee: Some Reflections on the "Inter" of International Relations
}

\author{
Michael Dillon
}

generated, political abjection. If that is one of the principal ends of international relations, one is forced to ask, what does it take as its beginning? If, in otherwords, the vernacular political architecture of modern international power commonly produces 1:115 forcibly displaced people globally, one is inclined to ask about the foundations upon which that architecture is itself based.

\section{Précis}

La réalitédu refugeest une scandale pour la philosophie en cela que le réfugié nous rappelle l'instabilité radicale de la signification et l'incalculabilité de l'humain. Mais le réfugié est aussi un scandale pour la politique en cela que l'avènement du réfugié est toujours un reproche d̀ la formation de l'ordre politique ou de la subjectivité qui suscite nécessairement l'apparition du réfugié. Le scandale est intensifié par toute politique del'identité qui présuppose que le but du politique est la réalisation del'identité souveraine. Le principal argument, dans ce cas, est que ce que jenommerais le scandale du réfugié illumine da la fois les déterminations ontologiques fondamentales de la politique internationale et le caractère de l'action politique, car le réfugié est à la fois une fonction de l'intentionnelle destruction politique des horizons ontologiques des mondes toujours-déjd hétérogènes des peuples, et il entraine une tout aussifondamentale destruction des horizons ontologiques qui constitue les mondes tout aussi hétérogènes dans lesquels, en tant que réfugiés, ces peuples sont précipités. C'est exactement sur ce site concret et corporel que les horizons ontologiques et les prises de décision corollaires de la politique moderne sont mis à nuet fermement remis en question. Carc'est exactement ici que l'action effective de la politique moderne crée et envisage les incidences de sa propre abjection politi- que, massive et autogénérée. Si cela est une des principales finalités des relations internationales, force est de demander que se donnent-elles comme point de départ? En d'autres termes, si l'architecture politique vernaculaire du pouvoir international moderne produit ordinairement 1:115 personnes globalement déplacées de force, on est en droit de poser des question sur les fondements sur lesquels repose une telle architecture.

"Ifyou gaze long enough into an abyss, the abyss will gaze back into you."

\section{Introduction: The "Inter" of International Relations and the Refugee}

Neither a co-national nor, even, another national, the refugee is, instead, distinguished precisely because $s \backslash$ he is located in the strange territory of estrangement which is located between the two; denaturalized, as a recent study of migrationnotes, having "nomeans of identification." 2 Neither in nor outwhile nonetheless, of course, actually bearing thename of some previousidentification on, and existing in a carefully defined no-where place within the boundaries of some other nation or state, so clearly also undeniably present-s/hebrings the very "Inter" of international relations to the foreground in a disturbing and unusual way, insisting that it become the concentrated focus of attention which it deserves to be.

In search of a home, because forcibly deprived, by violent and sustained political intent, of their previous home, the refugee brings to presence the very question of the home as such, and of its relation to politics. The refugee is a suppliant in search of a home, with pain- 
fully indeliblememories of a home that once was. Often with an abiding, seducing, nostalgia for a home that never was. For the violent event of displacement, of dislocation and subsequent diaspora, itself generates a necessary representation of home which inevitably calls into question what home was really like. No one knows what home was really like, however, because the home recalled is not the home that was and yetalso, the home that was could not have been the securely domesticated home one thought it was, because it proved so susceptible to radical dispersal and dissolution. The question of the home is therefore radically problematized by the unsettled, and is never resettled even when the unsettled regains a home. ${ }^{3}$

How, then, in all the senses of this term, is one to address the refugee? And how does that problem of address illuminate what the refugee illuminates about the human condition as such? For, while intentionally displaced, the refugee is not purposefully sent. Equally, while in desperate need of sustainable and survivable means of habitation, the refugee is not destined for some previously inscribed forwarding address. This experience-literally, of no known address-discloses something that is itself fundamental to the human: its very own lack of address, its own unsettledness. Theirnames erased, orBabelised, the places from which they fled changed beyond original recognition by the violence of expulsion itself, the refugee is one who-no longer safely responding to their previous namecannot be hailed securely by that original ethnic, religious, social or political designation. An administrative category for that which is no longer reliably fixed, locatable or designatable-one waiting in a sometimes interminable line, camp or holding-tank, for some other assignment-the refugee is human ors $\backslash$ heis nothing; or, at least, nothing but raw stuff. Here, then, is the inescapable and irresolvable, yet also practical and immediate-indeed, in our times massively posed-ontopolitical question, that the refugee brings topresence. What is to be human, when the human is precisely that which is in between-neither simply one thing, nor the other, precisely "inter" without a secure term or dwelling place? And how are not only politics but the thought of the political related to this question? The very advent of the being who is precisely without secure arid unambiguous home, identity or name, the refugee both raises our need while challenging our capacity to articulate or acknowledge the "we." That, I suggest, is not only the territory of the political in an age which has to be out-lived if the human is to have a future, it is also, and quite precisely, the territory of the inter of an international relations that is capable of out-thinking its own traditional designation; as a techne, skilled in calculating theinter-subjective political arithmetic of Modernity's given political subjectivities. For it is precisely that arithmetic obsession-the techne of modern political subjectification and governance itself-which now produces its own massive political abjection in the form of the refugee.

\section{The Refugee as Constitutive Outsider}

Exactlybecauses $\backslash$ he destroys the old trinity of state-nation-territory, the refugee, an apparently marginal figure, deserves on the contrary to be considered the central figure of our own political history. 4

What historical politicality-quality or project of being political, circumscribing the very domain of political intelligibility-is raised here by the advent of the refugee? What are we to make of what is going on when the political discourse of state-nation-territory does not merely enact that which it names-materializing the state, the nation and the territory-but the very "outside" upon which it draws for the articulation of $i t s$ most traditional legitimatory functions; representation of the people, and the monopoly not only of the legitimate use of forcefor the purposes of security but, also, the prior monopolistic determination of the definition of threat? What conclusions are we to draw from the following observations? That the harder a politics conditioned to secure the material production of the coherent identity to which its discourses refer, the more it seems to produce, "the unspeakable, the unviable, the nonnarrativizable ... the traumatic,"5 upon which it relies. Yet, also, the more it produces that which it cannot abide, the more the impossibility of its project is confirmed; such that, what remains outside the political subject, set there by the very acts which found the subject, persists as an integrally defining negativity. ${ }^{6}$ In what ways might this seemingly paradoxical political condition have become not only the condition but also the very occasion of some further, of some other, political thought and action?

This essay on the theme of the refugee is not, therefore, an essay in the largely policy analytic tradition of refugee studies. Neither is it simply an essay in identity politics, whereby the fear of the other, enemy or stranger is exploited in the contestation over the constitution of certain kinds of political subjectivity. The scandal to which it refers is a quite different register of scandal, also, from that in which we are usually invited to share when we are gathered by political and media representations of it to witness the spectacle of the refugee's abjection. Moving beyond that register of scandal, the essay offers a different one, and seeks as well to indicate the measure of its political implications, This register of scandal is plural. It refers to the scandal of the human as such. It addresses also the scandal of the inhospitability of the techne of modern politics: politics understood as techne, politics technologized by techne; politics whose end has become the application and operation of techne. Finally, and relatedly, it provokes the scandalous thought that the political project to which modern politics itself now gives rise is precisely not that of its self-realization: not that of the instantiation of sovereignty; not that of the securing of a home, not that of the resolution of alienation; not that, even, of the representation of thepeople. It is the challenge to out-live the global politics of Modernity itself. Out-live, that is, in all of the senses of that phrase: survive; exceed; tran- 
scend; live more fully than the totality which the modern in modern politics both promises and threatens: though it is, ordinarily, bound to renege on the promise and fail fully to realize it as a threat.

Different identity politics, of course, determine different things to be alien to them. How the alien appears, and the experience of the alien as alien, also waxes and wanes, however, according to different times and according to different philosophical systems. How the alien is alien similarly determines how the self-same-in both philosophy and politics-is itself not simply constituted, but continuously re-inaugurated in the process of trying to make the alien proper. There, therefore, brews not only beneath all identity politics, but also beneath all allied philosophical systems, a secret horror alieni that insidiously seeks to dispel all aliensaliennessitself - to divest things of everything enigmatic and strange. If they cannot do that, they seek, instead, to drive-out the stranger, making that estrangement the bearer of all that such systems find fearsome and threatening, evil, sinful and barbarous.

The constitution of any social group or political community is a matter of the exercise of inclusions and exclusions. The semantic field of the alien is, therefore, manifold and its political register is determinative of political community. All this is, by now, well-appreciated.

Mass expulsion and forceful displacement of peoples are not, of course therefore, a modern phenomenon. Equally, exile and diaspora are not exclusively modern experiences. But, if all philosophical systems, and all social and political grouping, are constituted on the basis of complex practices of inclusion and exclusion, then the nature of modern inclusions and exclusions are peculiar to and, therefore, do disclose something fundamental about, the particularcharacter of political Modernity, Albeit the point being explored here is not at all dependent upon the question of quantity, the sheer scale of the mass forced displacement of peoples globally in our times, for example, does seem to be distinctive, and it has given rise to analytical crises in those areas of study-migration and refugee studies, for example-as well as political crisis in those areas of national and international policy-making concerned with immigration, emigration, refugee protection, humanitarian intervention, asylum-seeking and regulation. ${ }^{7}$ That crisis serves here, however, as a pretext which, in addition, possesses a powerful rhetorical appeal for broaching a discussion which would apply even if there was only one displaced, one nonassignable, human being in the world.

The violent character of modern global estrangement also seems to be extraordinarily diverse. Consider, for example, the cast of out-casts which distinguishes modern forced displacement of peoples: refugee; political refugee; development refugee; internal refugee; asylum seeker; oustee; deportee; relocee; involuntary displaced person; involuntarily resettled person; forced migrant; involuntary migrant, and soon. Consider, too, the portfolio of policies that have given rise to them: war; internal security actions; lowintensity operations; pacification; ethnocide;genocide;pogroms; political repression; racial and religious discrimination; conquest; colonization; territorial appropriation; state-building; nation-building; self-determination; famine: urbanization; industrialization; and development. In 1993, out of a world population of about 5 billion the UNHCR estimated that around 1 in every 130 people had been forced into flight across state borders. ${ }^{8}$ Given the complexity and confusion surrounding the production and movements of refugees, together with the shifting legal politics of classification which characterizes the categorization of people as refugees, the precision of these figures is questionable and said significantly to underestimate the scale of the phenomenon. Later reports, "including people forced into flight within their own state territories, thus classifying refugees as part of an extraordinarily large and variegated global phenomenon of coerced displacement, therefore record that something in the region of 1 in 115 people find themselves in this condition. ${ }^{9}$

While, "there are as many reasons for moving as there are migrants," 10 globally - and it is now increasingly difficult for migration analysts and legislators alike to distinguish effectively between voluntary migration, involuntary migration, forced migration and expulsion-the production of the modern refugee is distinctive, and does differ from earlier, particularly nineteenth century refugees, in the way in which it is defined in terms of the wholesale devastation of the very ontological horizons of their worlds and their reduction to worldless beings unwelcome amongst the worldliness of others. Attributed to a complex combination of war; violent mass political repression; geo-political instability; regional and global economic transformation, in the form of the re-division and re-distribution of capital, labour and industry; man-made environmental disaster; and civil conflict, the overwhelmingly single most important reason now is, however, violent internecine conflict. The vast majority of refugees are precipitated by generic violence against civilian populations. "Virtually all of the refugee producing conflicts taking place in the world during the early part of 1993," according to the UNHCR study, "were within states rather than between them." ${ }^{11}$ Development studies have, however, documented how development itself also generates at least equal numbers of refugees as well. In short, the modern refugee is an (inter)national political production of its age and cannot but disclose the fundaments of it.

It is not my intention, however, to refine either the taxonomies of these modern out-casts nor that of the policies that have given rise to them. Taxonomies are generally concerned with advancing knowledgeable control of the objects of study by refining their categorization. I want, instead, to probe into what the refugee as such discloses about modern politics. I am concerned, on the contrary, therefore, with precisely that whichlike the refugee-while categorizable nonetheless exceeds categorization. For 
the refugee, like the human itself, is always both more and less than human, Thus, while the manifold ways in which expulsion and revulsion are experienced can be taxonomized, and taxonomic precision has its advantages in other forms of argument, expulsion and revulsion-the effect of being strange or estranged-always brings to presence the uncanniness of strangeness as such. That is to say, the uncanniness of Being within a category categorized as being without a category-that of the refugee-discloses the very uncanniness of the human itself, its improbable condition of always already containing both more and less than it seems it ought naturally to contain.

Because the constitution of any social group or political community is a matter of the exercise of inclusions and exclusions consequently does not mean to say that one set of inclusions and exclusions is the same as any other. Nor is it to say that because there have always been people who have been outcasts we can legitimately concentrate upon the native and the home, and thus forget about the stranger and the outside. On the contrary the "we" is integrally related to, because formed by, this relationship with the alien. Given the horrors inflicted upon the alien, it is understandable, indeed almost orthodox, to deny difference and urgently champion an all encompassing inclusion so as to mitigate or eradicate the terrors of exclusion.

Here, too, however, arises a further reverberation of the scandal of the refugee in the form of another scandalous thought. To be more fully "we" might precisely not entail being a more inclusive" we." The politicality of such a way of being would necessarily also comprise, therefore, other, precisely deconstructive, political entailments, practices, dispositions and sensibilities extending, and differing quite significantly from, those of any politics or project of inclusivity. It might, instead, entail different ways of thinking about, and different ways of seeking to entertain, that very relationship of alienness-what Nancy calls the "we" of being-with-which literally articu- lates us the human-expresses and joins, joins by expressing, links through the medium of Language itself.

All order, in short, encounters the alien or the strange which is defined not in relation to itself at all. Such alienness is beyond the trial of propriety to which strangeness is continuously submitted, including especially those codified in immigration and asylum-seeking procedures: a wonderfully "naïve" instance of which follows:

Are you or have you at any time been an anarchist, or a member of or affiliated with a Communist or other totalitarian party?

Have you advocated or taught, by personal utterance, by written or printed matter, or through affiliation with an organization (a) opposition to organized government; $(b)$ the overthrow of government by force; (c) the assaulting or killing of government officials because of their official character; $(d)$ the unlawful destruction of property; $(e)$ sabotage; $(f)$ the doctrines of world communism, or the establishment of a totalitarian dictatorship in the United States?

Have you engaged in or do you intend to engage in prejudicial activities or unlawful activities of a subversive nature?

Are you afflicted with psychopathic personality, sexual deviation, mental defect, narcotic drug addiction, chronic alcoholism, or any dangerous contagious disease?

Are you a pauper, professional beggar or vagrant?

Are you a polygamist or do you advocate polygamy?

Have you committed or have you been convicted of a crime of moral turpitude ${ }^{12}$

These are among the questions you would have to answer should you be seeking to join, and be accepted as a proper member of, the United States. Other trials of propriety, however, are more Kafkaesque than farcical.

The alienness to which I am referring now concerns an alienness which is not the property of any person, people, place or thing. It does not belong to entities, albeit that it comes to presence in the appearance of persons or things.
Propriety does not attach to it all. Hence it is not a property of the world but an indelible, if fugitive, aspect of the world within whose horizon it is continuously and variously encountered. The semantic field, and thus also the political register of the alien-here through the figure of the refugee-in always disclosing this alienness, consequently also simultaneously always betrays the philosophical register of the horror alieni as well. Buried in the political register of that horror alieni is therefore also something more fundamental about the fundaments of being that philosophy, and thus political Modernity, is inclined to express.

For the refugee alerts us to, by bringing to presence our awareness of, a different ontological condition definitive in many ways of the ontological turn; that of the ontological difference between beings and Being as such. Recognition of the ontological difference is recognition of the mutually disclosive belonging together of Being and beings - of theexcess that always already inhabits the being of human being, whose absent presence does not come to presence as such - which gives rise to the deconstruction which is always already at work in the coming to presence of human being and of Language; the mode in which it comes to presence. Thus deconstruction is less a technique than the irresistible consequence of the ontological difference whose play makes of human being a free and incompleteplethos.

Alert to this ontological dimension of identity politics, we can be alerted also to that other register of scandal to which I referred in my opening. It is that strangeness, then, the strangeness which comes to presence with the advent of the stranger or the alien, takes this essay not only through but also beyond identity politics-where the alien or the stranger is regarded as virulent because the idea of order is premised upon the operation or realization of a unity, even of an ensemble of many beings-to scandalizes its philosophical underpinnings: traditional understandings of the idea-the eidosof unity as such. For the advent of any 
stranger is the limit at which the integral and indelible strangeness of the human condition as such makes its appearance.

Accepting that other times and other forms of life have treated strangers badly, or manufactured strangers of themselves, does not, then, deny that modern estrangement happens in its own modern way and for its own modern reasons. We can therefore note that ourage is one in which political order is not simply premised upon the realization of a unitary but on a certain kind of technological, utile uniformity of, identity; in pursuit of which the very activities of their own states, together with the global capitalism of states and the environmental degradation of many populous regions of the planet, have made many millions radically endangered strangers in their own homes, as well as criminalized or anathematized strangers in the places to which they have been forced to flee. Although we have some sense of why it was, it is, nonetheless, still utterly astonishing thatwhile millions upon millions of people were engaged in massive Trans-oceanic Euro-American and intra European migration, itself accompanied by the forcible transfer of at least equal numbers of people through the globally commercialized slave trade and, later, the so-called "coolie migration" - it was insisted that politics be understood as grounded upon a secure triangulation of territory, nation and state; when the facts so massively spoke of the mobility of people, the mutability of boundaries, the "mongrel-arlry" of nations and the specular artificiality of the state.

The scale of the politically instrumental-deliberate, legal and policy-initiated-manufacture of estrangement in world politics necessarily calls into question, therefore, the very moral and political foundations and accomplishments of the modern age; particularly those of the state and of the international system of states.

In such circumstances-and given the vaunted political and moral claims made on behalf of states and of the international state system, as well as of so-called international society-we seem increasingly left not knowing to what symbolic space, to what understanding of the human way of being, we can entrust what we variously call freedom and humanity. ${ }^{13}$ Modern politics, the politics of Modernity, continuously undermines, however, its own most violent, most intense, most totalizing attempts to securely free humanity. And this is not because of some technical deficiency on its part the global politics of Modernity is the expression of politics as techne. It is because it is not realizable. In the process the modern expression of identity politics, while thus disclosing something also about themodern world's response to strangeness as such, provides a powerful intimation that the reception which the modern we accords the strangeness of the human way of being is what the very dis-order of political modernity itself calls into question.

Specifically, modern political subjectification creates its own peculiar form of political abjection. Originally applied to French Huguenots who fled to England after the revocation of the Edict of Nantes in 1685-and therefore a direct function of early modern absolutist understandings of the entailments of stable, legitimate and authoritative political order, and their consequences-the refugee is precisely the figure which identifies the political abjection of the modern age.

Abject means cast-out, abjection means also the act of expelling. It marks the failure of the political subject to be a pure political subject even in the act of trying to realize that ideal. Marking the porosity of the limits of that which seeks to be the self-same, it is the waste which continuously disturbs identity, system and order because as the outside reproduced by the inside it continuously irrupts in a way which erodes the very parameters by which the inside seeks to be defined. That which the effort to subjectify creates, its production marks the impossibility-the abject failureof what modern political subjectification idealizes and aims to realize. For the political practices of burning, chasing, raping, expelling, degrading, murdering, humiliating, terrorizing, excoriating, removing, burying, hiding, suppressing and devastating, invent and re-invent the very waste they name and exorcise in the process of continuously re-inaugurating, as politics, a certain imperative of political unity and malleable uniformity. Waste, as Ricoeur noted, is not waste without its wasting processes; its protocols of purgative production. ${ }^{14}$ Neither is it undifferentiated since its processes of production are themselves plural. Abjection-the systems own self-produced and selfproducing perturbation-is neither inside nor outside but the in-between, boundary or limit which enacts the differentiation. Abjection is (inter)national politics, and as (inter)national politics it insists on a preoccupation with the inter anterior to the national.

Since the seventeenth century, of course, while the international definition of the refugee specifies the crossing of state borders, the incidence of "refugeeism" - to coin an awful neologism for an awful condition-has been extended in many intensive ways to the massive forced re-location of peoples within their existing territorial boundaries and for the purposes of "development" and, "resettlement" rather than of traditionally religious or political persecution. Social Scientific research on involuntary resettlement mushroomed between 1984 and 1994 in response to the discovery that World Bank funded development projects-notably those concerned with the building of large-scale dams-manufactured massive impoverishment instead. ${ }^{15}$ Complexly complicit in the violent appropriative and exploitative politics of the political and economicelites of the recipient states, politically mandated mass re-locations of people did not merely enrich some and pauperize most, in ways systematically related to the mutations of global capitalism, but effectively and radically de-worlded those who were resettled. That in turn provoked reformations of identity borne out of resistance to the experience itself. Here, then, is a further mutation of the processes and protocols of the production of abjection which discloses something else about the governmental 
imperatives of politics in late modern times. In consequence:

Development-caused displacements, that seemed to be piecemeal occurrences and were estimated as totaling far less than the number of refugees worldwide, have turned out to be $a$ much larger process than all the world's new refugee flows. Refugees and development displacees, of course, are not "numbers" that compete with each other, but are global parallel dramas sometimes intertwined. ${ }^{16}$

The principal difficulty with the overwhelming volume of this research is, however, the propensity to de-politicize the issue by translating it into precisely that technical policy-analytic enframing which contributed to the production of the problem in the first place. Technology thus translates the question of the political into certain kinds of problematizations; requiring rigorous calculability, utility, and governmentality. It then feeds itself on the history and further elaboration of the very problematizations it introduces. ${ }^{17}$

Albeit, then, the theme of abjection also arises here, the essay is not a treatment of the refugee as victim. Refugees have always offered, and been, more than mere objects of pity and suffering, something which the Huguenots themselves, of course, also demonstrated. ${ }^{18}$ As abjection, the refugee consequently also calls into question the foundational underpinnings both of the community from which $s \backslash$ he has been expelled and the community into which they seek to be received. What is at issue, in short, is the very question of human dwelling and belonging in a world. That in turn raises the point, well-made by Judith Butler in another discussion, of how "such socially saturated domains of exclusion" be recast from their status as constitutive outsiders, "to beings that matter." 19 I take the refugee to be a being that matters in respect of the world (dis)order of political modernity, the requirement to out-live it, and the possibility of the possibility of doing so. The essay is thus, instead, a contribution to what the political theorist William Connolly has called ontopolitical interpretation.
By the ontopolitical Connolly refers tothe way in which every political interpretation invokes a set of fundaments about the necessities and possibilities of human being; about, for instance, "the forms into which human beings may be composed and the possible relations which humans may establish with nature." 20 For the on, or the onta, of ontology refers to the reality of really existing things. In making his point about the way in which all political interpretation is simultaneously also ontopolitical because it cannot but disclose the ontology sequestered within it-to repeat: making any statement about what is, is always already to find oneself within an understanding of the is as such-Connolly demurs at the logos of ontology because he finds the idea of the logic of reality apart from appearance too determinative and restrictive. It suggests a principle or design of being, when it can and has, of course, been argued that the fundamental thing about being is that it exhibits no such overriding logic or principle.

Surveying the various means by which modern political thought has elided the ontopolitical-modern secularism, pragmatism and epistemological realism, for example-Connolly concludes that this elisionalso obscures a convergence of ontological views. Asking rhetorically, "What if some common presumptions of our times ... contain dangerous demands and expectations within them? What ... if the points of ontopolitical convergence in the late-modernnation-state turn out to be exactly the domain in need of reassessment today?"21 Connolly notes that this is precisely what that strain of thinking from Nietzsche onwards contends "that every detailed interpretation presupposes answers to fundamental questions of being, and that this is indeed one of the territories of modern discourse that requires critical reflection."22

My contention is that the advent of the refugee brings that very territory of modern discourse directly into question, because the refugee is a function of the dangerous ontopolitical convergences which Connolly notes. Specifi- cally, that ontological narcissism, to which he refers in his essay on "Freedom and Contingency," in which freedom has become associated with the security of being in command, the corollary of which appears to mean being subjected to intensifying control. ${ }^{23}$ Amongstother things, therefore, out-living the modern is critically associated also, therefore, with out-living these dangers. The advent of the refugee-one whose very own ontological horizons have been devastated; one removed from a world-thereby dramatically exposes and radically disrupts the ontopolitical horizons not only of the hosts in which they arise, but also of political Modernity as such. Finally, the essay seeks to draw-out a significantly different set of ontopolitical suppositions which the advent of the refugee also helps to disclose.

If this provides some early, if all too brief, an indication of what I mean by out-living the modern, I cannot give some comparable and positive indication of what I mean by the scandal of the refugee, however, without also elaborating the very different ontopolitical fundaments which the advent of the refugee brings to presence. Just as Connolly draws on a certain range of philosophical resources to make his point about the elisions and dangers of the onto-politics of late Modernity, I draw upon the same resources to offer this alternative ontopolitical account of the human; in which its estrangement from itself is the very scandal that the refugee brings so forcefully and politically to presence in the (dis)ordering of world politics. It is that estrangement, as itself an ontopolitical point of departure, which is both thecondition and the occasion of another politics.

\section{The Ontopotitical Condition of Worldly Estrangement}

What becomes of being-with when the with nolonger appears as composition, but rather as dis-position? ${ }^{24}$

In excess of the humanitarian scandal of the refugee, and in excess of the policy analytic and policy-making crisis induced by the astonishing growth of refugees in the past ten years. In excess, also, 
of the political crisis which the advent of large numbers of refugees excites in the countries to which they flee, or of countries like the United Kingdom in which the narcissistic politics of identity seems designed to go phobic at the least provocation of alienness, the scandal of the refugee is not only the scandalous thought that political Modernity has to find a way of out-living rather than of realizing itself. In excess of, but also in alliance with these other registers of scandal, the advent of the refugee always brings to presence this: the scandal of the human as such. That scandal is the scandal of human freedom which makes both politics and law possible without making either politics or law certain. It is a scandal from which the telic understandings of politics, as a form of making that results in a technologizing of politics seeks to save us; and in the process subjects us to novel, possibly terminal, globalized terrors and dangers.

Human being is a mobile way of being on its way from birth to death which lives life without owning whatever gives life. It is, then, in the condition of an originary dis-possession because it enjoysnosecurity of tenure over the freehold of its existence. That leaves it in the curious position of having to own itself without possessing original title to itself. It simply does not, and cannot, possess a secure property right in itself, of itself. In consequence, it makes-up wonderfully implausible stories to account for this predicament and binds itself to, and with, them in the hope that they may make such a peculiar way of being somewhat easier to bear. Technological mastery of ourselves and "nature" through submission to the spectacular power and productivity of representativecalculative thought, projected on and through, rather than grounded in, the idea of a sovereign reasoning subject, is the specular mythological achievement which distinguishes and determines our own politically modern times.

Philosophers (some philosophers) call this difference-the difference between beings that exist and existence as such-the ontological difference. In- sinuated into the very being of human being it is what makes human being plural more than one. That plurality is not, it should be noted, the plurality of many human subjects, however those subjects are specified: people; nation; class; race; religion; or even citizen (by virtue of subscription to the constitution of a republic and its civic culture). An even more disturbing phenomenon, that plurality is what might be called an onto-plurality. Installed within the being of every human being, the plurality of such a difference is not an Hegelian relational concept of difference either, in which difference-some would call it Otherness-is only difference in relation to me and, therefore, not truly different or Other at all. ${ }^{25}$ Rather, it is an irreducible and irremissible Otherness or difference which, constitutive of human being, is nonetheless beyond its mastery. What identifies human being-its freedom, in raising and answering the question of its own existence, also to recognize this Otherness or difference which is integrally constitutive of it-is simultaneously what disrupts its identity with itself as well.

Enjoying an existence which is plural as such-itself a plethos rather than merely comprised of a plurality of beings-the human inhabits a strangeness which also inhabits it. A being that is itself radically transitive, occurring through time and so originally historical rather than merely mobile, the worldly estrangement of human being is an interrogatory way of being that, in having only itself hermeneutically to answer to, is, nonetheless, in the position of having to answer to a mystery. ${ }^{26}$ To be worldly here is to have a certain modality of alienation "inscribed at the heart one's existence, and to give this alienation an extremely positive validation. ${ }^{27}$ On its way from birth to death, and consequently therefore always already on themove into a future in which it becomes that which it has never yet been, human being thereby necessarily also remains fundamentally a stranger to itself. The scandal of the refugee is that the human is itself not simply natural, not-to play on the scan of scan- dal-reliably metrical. Calculative, it nonetheless simply does not add-up. The scandal, in short, is that the human is itself alien-, in that while of necessity it dwells in a world, it is not, and cannot, befully at home there: because it never received vacant possession, does not own the freehold and has no security of tenure in it. The hope which, therefore, arises with the refugee exceeds the hope that the alien might find a "home," and entertains the possibility that the onto-alienness of human being might ultimately also find ways of being hospitable to itself. Finding such ways and articulating such a hope are, I believe, also ways of newly-understanding the project of democratic politics, provoked by the advent of the refugee and dramatized by the dangers of world (dis)order in late-modern times.

Such a condition-freedom to give the law that is a freedom before the law of that which is, in Nancy's paradoxical phrase, "legitimately without law (de droit sans droit)"28 - is not just a scandal to reason, it is also ethically scandalous as well; which is to say, "a snare, trap, or cause of moral stumbling ... a stumbling-block" [OED]. Continuouslyhaving to find its feet, the human way of being is thus simultaneously, also, the occasion of its downfall as well. Nothing bears it up in its disposure other than its composure. That composure, however contrived, even under modern forms of representative democratic government which ground their legitimacy in the representation of "the people," is a fallible act made possible in virtue of that ontological freedom. Such composure is not, however, the telos or end of a politics of making, of politics understood to be a process of fabrication. Rather, it is the endless work of assuming the burden of being free, in laying down the law, to be interpreting thelaw in consequence of the exception to the law which the law itself necessarily brings to presence. To have an end is only possible in the condition of not having any end as such. Political-I would add, democratic-composure is the deferral of the end that would end all purposefulness. It is a tricky act to pulloff because, continuously disrupted by, 
human being has nonetheless continuously also to come to terms with, its original disposure; its thrownness into a world in which it knows not from whence it came, nor where it is headed.

To note and consider the ontologizing effect of the refugee, however, does not mean abandoning the economic, political or personal dimension to the refugee, any more than it means abandoning the terrain of judgment. The ontologizing effect does not remove us to some abstract or speculative region at all. It is a question of entering these other so-called empirical, but in Arendtian and Heideggerean language simply worldly, regions differently. For the word means the thought of existence and the status of it today means thinking our, especially political, existence on the level of the challenge which the refugee brings to our capacity less to secure a home and more to create and live in habitable worlds. Hence, we are ontopolitically indebted to the refugee. That debt cannot be repaid, but it can be explored and acknowledged through a political thought other than that which has helped to make the refugee one of the principal bearers of the cost of the political (dis)order of the modern world, where the technological understanding of politics as fabrication-state-building; nation-building, nation-statebuilding, hegemonizing; counterhegemonizing - is paramount. Tóbring the derelicted into thought in this way is neither to patronize, nor to avoid, the devastation of their dereliction. It is an exercise neither of good nor of bad conscience. It is to respond positively, instead, to the refugee's profound provocation of political thought; by which I mean their provocation both to think politically and, in thus thinking politically, to think against the ontopolitical convergences which distinguish modern political thought.

For the refugee raises the question of association beyond, outside, in themargins, or in excess of, established political sociation; because the refugee is by definition a-social, a-political. Being political, one might say the being of politics, is profoundly at issue here, then, in and through the presence of the refugee. The figuration of the abjection at the heart of modern political subjection, of the associational poverty at the centre of so much political sociation, and of the impoverishment of beingwith in today's global togetherness, the refugee exposes how belonging together politically has become belonging together at the production of the spectacle of politics, including that of the abjection integral to it. The advent of the refugee nonetheless still ruptures the horizons-spoils the show-of societies which desire to be left only to themselves, seeking to affirm their social and political being by reference to no horizon but themselves. What emerges from taking the refugee even more seriously, therefore, than, say, refugee studies might perhaps unfairly be said to do, is not the idea of some sovereign individual or communal, rights-based, understanding of human being, however, which requires extension to the being which has been expelled from its world.

The problem with rights here in this argument concerning the politically dislocating ontologizing effects of the advent of the refugee-that is to say, aside from any tactical questions concerning the provision of some means of protection to the outcast-is that it appeals to one of two grounds, each of which is equally unsustainable in the face of the alienness that the refugee brings to presence. On the one hand, rights are the fruit of the enforceable law of a community. On the other, rights are said to be the natural endowment of what it is to behuman. The refugee is, of course, refugee in virtue of its expulsion from, and very often by, the enforceable law of a community, There is noenforceable communal law-UN conventions on refugees are just that; conventions which the existing legal communities of statesinterpret for themselves, and may or may not apply to themselves-to which the refugee has recourse. ${ }^{29}$ That is the point to being a refugee. Conversely, the appeal to what is said to be the natural endowment of the human raises the ontological question of the natural. Here the advent of the refugee is radically disruptive because the event of the refugee's alienness calls to mind the alienness of the human as such: the very non-naturalness of the onto-plurality; throwness and responsibility of its abyssal freedom. For if the human were simply natural it would not have this freedom-with all its attendant burdens of decision-to be.

The question of taking the refugee even more seriously is not, however, simply a question, either, of some sociality or alterity that problematizes the authority of the subject understood as a solus ipse: "It is more than this and something else entirely." ${ }^{130}$ It is a matter of the ipse itself, of its very belonging together in and through its inherent plurality. That with which we are associated, and that which associates us, in short our capacity to say "we" the human, is what is at issue; mundanely, corporeally; and increasingly, in our world, massively. Theadvent of therefugee, therefore, poses both the ontological question politically and the political question ontologically. Hence the dramatic, and dramatically disruptive, ontopolitical valence of the refugee. Neither a neighbournor a friend, linked by neither a politically fraternal, communal nor national bond, the advent of the refugee poses the question of the "we" of the human as such and discloses its co-ipseity beyond, or other than, our current understandings of the belonging together of the human way of being. That co-ipseity is obscure, enigmatic and opaque. Readily deniable, it is nonetheless also impossible to escape. Inescapably ethical, its inescapability has also gone global, and sets-up aporetic perturbations in all settled systems of political order and understanding, including those of Communitarian and Liberal thought. ${ }^{31}$ Michael Walzer, for example, admits as much.

At the extreme, he notes in Spheres of Justice,"the claim of asylum is virtually undeniable. I assume that there are in fact limits to our collective liability, but I don't know how to specify them." But if that is true, he went on, "why stop with asylum? Why be concerned with men and women on our territory who ask to remain and not with men and women oppressed in their own coun- 
tries whoask to come in? Why mark-off thelucky or aggressive, whohave somehow managed to make their own way across our borders, from all others? Once again I don't have an adequate answer to these questions?" 32

Raising the question, the capacity, and our necessity to be able to say "we," the refugee does so in circumstances which are authorized, therefore, neither by God, the Leader, theNation, theState, nor the People. Rather, the refugee raises that need in the circumstances in which none of these ontopolitical figures says it for us. The refugee does so, and crucially, in precisely those circumstances when these figurations of the ontopolitical convergences of modern times-those very ontopolitical signifiers which operate as rallying points for mobilization and politicization fated nonetheless to dishonour their promise, "both to unify the ideological field and to constitute the constituencies they claim to represent," 33 _tell us, instead, exclusively to say "I." Not being able to say "we" in the circumstances in which it is mostcalled for-that is to say, when we are not authorized to do so, and when it is the strange and different that we are entertaining, is precisely, however, what allows each " $I$ " the dementia which results ultimately in individuals not being able to say " $I$ " any more either. That is what makes the refugee a touchstone of the very democratic politicality of any community-its capacity, in making way for other beings, to make way for other ways of political being to be in its very own way of being. ${ }^{34}$

The "we" is in question as a question, then, when faced with the refugee because the refugee poses the very questionability of the "we" at us directly and politically, but in a way in which the answers we have currently settled upon-and in-nolonger answer. That "we" obliges us to find other ways of saying "we" again, and through that inescapable insistence binds us in a peculiarly ethical form of "commonality." Once more our ontopolitical indebtedness to the refugee surfaces, for the refugee attests to the very aporeticness of the "we" and re- opens it for us. In the process-precisely because the "we," however enigmatically, is-we, however we are, are continuously re-configured. Herein, then, lies the intimation of the possibility of a different ontology of the species of political being: of one always already. strange to itself, one more equipped to address the plurality always already insinuated into being. Here the "with" of association is what the political takes as its question not as its ground, precisely because it is human being's very own questionability. And it assumes as the commission of that very omission, precise lack of any secure answer to what the human is, the commitment to keep the with of that indefinable "we" open.

I want to conclude, then, in a kind of amplified and intensified Arendtian way. It is this plethos which allows for the very possibility of politics; because it constitutes an ontological freedom which, in distinguishing human being as the way of being which is obliged to raise and respond to the question of its existence, without ever being in a position to answer it, devolves upon it the responsibility to lay down the law, and thus order its own affairs. It is not simply, then, the question of the "inter," but of its very irresolvable questionability, that gives rise to politics at all.

I would call that politics democratic which did not merely claim to represent "the people," did not begin with a subject individual or collective, but was committed instead to continuously forestalling the foreclosure of freedom entailed in having to give an answer to the question of the self and of the community. I would also call that politics democratic if it was one which was thus committed to the project of keeping open the question of who "the people" (the deinos) is, that is, of continuously disclosing, rather than foreclosing, the "inter" or "we" in the human way of being. Democracy to come would thus be-always already is - the forestalling of the foreclosing of this questionability; even in its own foreclosing. ${ }^{35}$ Is it not this which constantly takes place in the "Inter" of international relations; despite what international relations once thought itself to endorse, as knowledge and as politics, and so to be as a discipline?

\section{Notes}

1. Friedrich Nietzsche, Beyond Good and Evil, translated by R. J. Hollingdale (Harmondsworth: Penguin Books, 1990), $\# 146,102$.

2. Sarah Collinson, Europe and International Migration (London: Pinter for RIIA, 1994), 37.

3. See, for example, Daniel Warner, "The Community of the Refugee," International Journal of Refugee Law 3, no. 4 (1991), 73134. More philosophically, see, Robert Bemasconi, "On Deconstructing Nostalgia for Community in the West: The Debate Between Nancy and Blanchot, "Research in Phenomenology 23 (1993), 3-21.

4. Giorgio Agamben, "Beyond Human Rights," Liberation, 9 June 1993, 8 (my translation).

5. Judith Butler, Bodies That Matter: On The Discursive Limits of 'Sex' (London: Routledge, 1993), 188.

6. See also Slavoj Zizek, The Sublime Object of Ideology (London: Verso, 1989).

7. See, Aristide Zolberg, "The Next Waves: Migration Theory For a Changing World," International Migration Review 23, no. 3 (1988), 403-30; Christopher Mitchell, "International Migration, International Relations and Foreign Policy," International Migration Review 23, no. 3 (1989), 681-708; and, classically, the recent report from the UNHCR, The State of the World's Refugees: The Challenge of Protection (Oxford:Oxford University Press, 1995).

8. UNHCR, The State of the World's Refugees.

9. Hans Thoolen, Regional Representative for the Nordic and Baltic Countries of the UNHCR, Report, 10 October 1994.

10. UNHCR, The State of the World's Refugees, 13-14.

11. Ibid., 14-15.

12. I am indebted to David Campbell's provocative study Writing Security (Manchester: Manchester University Press, 1992), 41 for this list.

13. Jean-Luc Nancy, "War, Law, Sovereignty-Techne," in Rethinking Technologies, edited by Verena Andermatt Conley (Minneapolis: University of Minnesota Press, 1993), 28.

14. Paul Ricoeur, The Symbolisation of Evil (Boston: The Beacon Press, 1969).

15. See Michael M. Cernea, Involuntary Resettlement in Development Projects. Policy Guidelines in World Bank Financed Projects (Washington: World Bank Technical Paper 
80, 1988); Tribal Peoples and Economic Development. Human Ecological Guidelines (Washington: World Bank, May, 1982); Deoelopment in Practice. Governance. The World Bank Experience.(Washington:World Bank, May, 1994); Leila C. Fnischtak, Governance Capacity and Economic Reform in Developing Countries (Washington: World Bank Technical Paper 254, 1994); Resettlement and Development: The Bank-wide Review of Projects Involving Involuntary Resettlement, 1986-1993 (Washington: World Bank Environment Department, 8 April, 1994).

16. Michael M. Cemea, "Understanding and Preventing Impoverishment from Displacement. Reflections on the State of Knowledge," in Resisting Impoverishment: Tackling the Consequences of DevelopmentInduced Population Displacement and Resettlement, edited by C. McDowell (Oxford: Berghahn Books, 1995).

17. See Graham Burchall et al. (eds.), The Foucault Effect (London: Harvester Wheatsheaf, 1991).

18. This point could, and has, been argued in book-length studies. See, for example, Collinson, Europe and International Migration. It is an important corrective to the ways in which economic, racial and other fears of the outsider are habitually exploited in domestic politics. In consequence, it is ironic to note that at the height of the most recent employment of the fear of the outsider in British politics, and a further restricting of asylum to the United Kingdom, that a research study of the British Home Office should have provided further evidence for the point. See, Jenny
Carey et al., The Settlement of Refugees in Britain (London: Home Office Research Study 141, HMSO, 1995).

19. Butler, Bodies that Matter, 189.

20. William E. Connolly, "Nothing is Fundamental," The Ethos of Pluralisation (Minneapolis: University of Minnesota Press, 1995), 1-40.

21. Ibid., 4 .

22. Ibid.

23. William E. Connolly, "Freedom and Contingency," in Life-World and Politics: Between Modernity and Postmodernity, edited by S. K. White (Indiana: Notre DameUniversity Press, 1989).

24. Jean-Luc Nancy, Being-With (Colchester: University of Essex Centre for Theoretical Studies Working Paper No. 11, 1996), 5.

25. See, Rodolphe Gasche, Inventions of Difference: On Jacques Derrida (Cambridge, MA: Harvard University Press, 1994).

26. This is, of course, the radical hermeneutical approach to the human condition, derived from Heidegger's radical phenomenological and hermeneutical moves. See the following for an account of its development and character: John Caputo, Radical Hermeneutics (Bloomington: Indiana University Press, 1987); Gerald Bruns, Heidegger's Estrangements: Language, Truth and Poetry in the Later Writings (New Haven: Yale University Press, 1992); and Bruns, Hermeneutics Ancient and Modern (New Haven: Yale University Press, 1992).

27. Dana Richard Villa, Arendt and Heidegger: The Fate of the Political (Princeton, NJ: Princeton University Press, 1996), 203.
28. Nancy, Being-With, 6.

29. See Michael Dillon, "Sovereignty and Governmentality: From the Problematics of the New World Order to the Ethical Problematic of World Order," Alternatives, 20 (1995).

30. Nancy, Being-With, 5.

31. See, for example, how Thomas Dumm explores this point in relation to Charles Taylor in, "Strangers and Liberals," Political Theory 22, no. 1 (February 1994), 16775.

32. Michael Watzer, Spheres of Justice. A Defence of Pluralism and Equality (Oxford: Basil Blackwell, 1983), 51. The difficulties lie, of course, in pluralism and equality-a phenomenological symmetry and asymmetry (to use Derrida's Levinasian gloss on Heidegger)-which radically disrupts Walzer's project. It is precisely that phenomenological symmetry and asymmetry which the refugee brings so forcefully and corporeally to presence.

33. Butler's gloss on Zizek, in Bodies That Matter, 191.

34. I work this point out of Nancy's BeingWith. I am generally indebted to the thought of "freedom" and "being-with" which he has developed in the following: The Experience of Freedom (Stanford: Stanford University Press, 1993); The Birth to Presence (Stanford:Stanford University Press, 1993); and, The Inoperative Community(Minneapolis: University of Minnesota Press, 1991).

35. Connolly, The Ethos of Pluralisation. $\square$

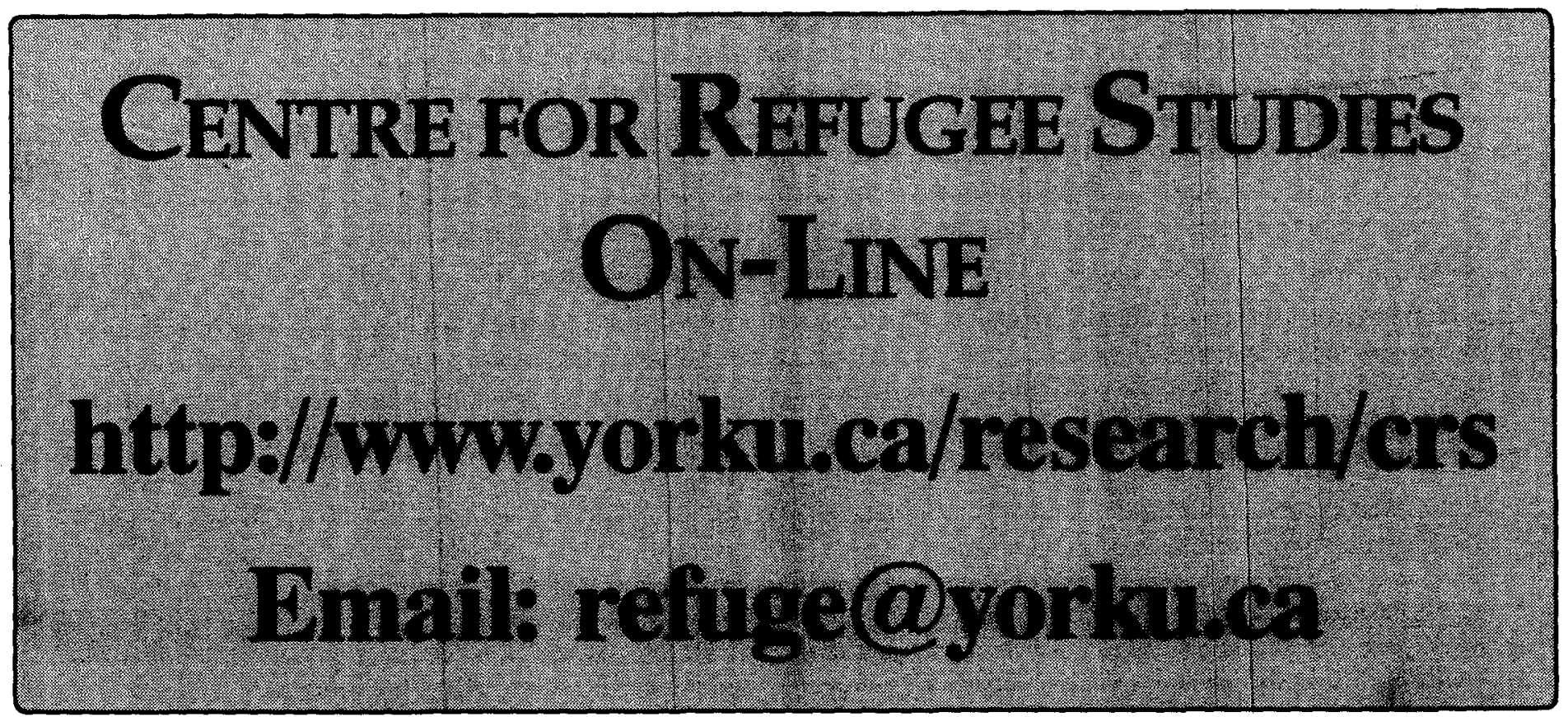

Refuge, Vol. 17, No.6(December 1998) 


\section{States and Strangers: Refugees and Displacements of Statecraft}

\section{By Nevzat Soguk}

University of Minnesota Press, March 1999; Cloth ISBN 0-8166-3166-2; \$62.95; Paper ISBN 0-8166-3167-0; \$24.95; 340 pages; indexed

States and Strangers looks at the role of refugees in international relations.

Refugees may flee their country, but can they escape the conflicting, defining logic of all voices that speak for them? As refugees multiply in our troubled world, more and more scholars, studies, and pundits focus on their plight. Most of these attempts, says Nevzat Soguk, start from atnodel thatShares theassumptions manifested in traditional definitions of citizen, nation, and state. Within this hierarchy, he argues, a refugee has no place to go. States and Strangers questions this paradigm, particularly its vision of the territoriality oflife.

Aradical retheorization of the refugee from Foucauldian perspeCtive, the book views the international refugee regime not as a simple terriaryresponse, arising from the practice of states regarding refugee problems, but as itself an aspeCt of the regimentation of statecrafr. The attendant discourse negates the multiplicity of refugee events and experience; by aSsigning the refugee an identity-someone without the citizen's grounding within a territorial space-the states renders him voiceless and deprives him of representation and protection. States and Strangers asks how this happens and how it can be avoided.

Using historical, <l.t'cl1ivoUxesearcl1 andinterrretive strategie\$ drawnfrOm agenea1ogicalapproach, Soguk considers the role of the refugee in the emergence and maintenance of the sovereign territorialstateform the late seventeenth century to contemporary times. NevzatSogukis assistant professor of political science at the University of Hawaii at Manoa.

"States and Strangers comes down from the heights of the lofty ivory tower to combinesophiscicated theoretical significance with the concerns ofrealpeople theypavigatetheirdailyexistence in worlds that botljscl1olarsand policy makerS often ignore; Professor Soguksuccessfully integrates scholarlyrigorwiili the desire to create a space that refleCts the humanity, dignity, and capacity for agency that refugees possess. States andStrangers ranks among the best in engaged scholarship.»

Roxanne Doty, Arizona State University, and author oflmpfrialEncDunters

"This oookisan importantcontribution to understanding how refugees as outsiders help in the discourse of national consciousness and are a crucial element in modern statecraft. Soguk takes the refugee experience as a metaphor for the "modern condition and problefuatizes the categorization of refugees outside the traditional confines of nation-statecicizenship. By rereading certain historical events such as the Hugue.n9tdisplacemc:nt amhhe creation of the League ofNa,tlonsHigh Commissioner for Rc:fugees, Soguk offers a new perspective on the relationShip betWeerihUinan flows, the practice of statecraft, andtheinternational system. This is a challenging work that goes beyond traditional analyses of the development of the refugee regime to question the state-centridterritorial basis of that regime.»

Danid Warner, Graduate InstituteofImernational Studies, Geneva, Switzerland 